\title{
Association of interleukin-10 gene polymorphisms with breast cancer in a Chinese population
}

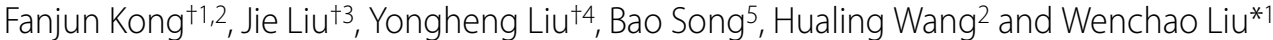

\begin{abstract}
Backgroud: Interleukin-10(IL-10) is a multifunctional cytokine with both immunosuppressive and antiangiogenic functions. Polymorphisms in the IL-10 gene promoter genetically determine interindividual differences in IL-10 production. This study was performed to determined whether polymorphisms in the IL-10 gene promoter were associated with breast cancer in a Chinese Han population.
\end{abstract}

Methods: We genotyped 315 patients with breast cancer and 322 healthy control subjects for $-1082 \mathrm{~A} / \mathrm{G},-819 \mathrm{~T} / \mathrm{C}$ and $592 \mathrm{~A} / \mathrm{C}$ single nucleotide polymorphisms in the promoter region of the IL-10 gene by polymerase chain reactionerestriction fragment length polymorphism (PCR-RFLP).

Results: There were no significant differences in genotype, allele, or haplotype frequencies in all three loci between patients and healthy controls. Analysis of breast cancer prognostic and predictive factors revealed that the -1082AA genotype was associated with a significantly increased risk of lymph node $(L N)$ involvement $(P=0.041)$ and larger tumor size $(P=0.039)$ at the time of diagnosis. Furthermore, in the haplotype analysis of IL-10 gene, we found that patients carrying ATA haplotype were in higher LN involvement $(p=0.022)$ and higher tumor stage $(p=0.028)$ of breast cancer at the time of diagnosis compared with others.

Conclusions: Our findings suggest that IL-10 promoter polymorphisms participate in the progression of breast cancer rather than in its initial development in Chinese Han women.

\section{Introduction}

Breast cancer is the most common malignancy threatening the health and life of women and it's incidence has increased in recent years in both developed and developing countries[1]. Biologic mechanisms leading to the development of breast cancer are not clearly understood, but the role of cytokines in cancer immunity and carcinogenesis has been well established[2]. As a multifunctional Th2-cytokine with both immunosuppressive and antiangiogenic functions, interleukin-10 (IL-10) may have both tumor-promoting and tumor-inhibiting properties[3]. Recent data suggest that polymorphic variations in the promoter sequences of IL-10 gene may influence the gene expression $[4,5]$ and consequently play a certain role in susceptibility and clinical course of breast cancer.

* Correspondence: xjcancer@163.com

1 Department of Oncology, State Key Discipline of Cell Biology, Xijing Hospital, Fourth Military Medical University, 710032, Xi'an, PR China

+ Contributed equally

Full list of author information is available at the end of the article
IL-10 is an important immunoregulatory cytokine mainly produced by activated $\mathrm{T}$ cells, monocytes, B cells and thymocytes. As an immune response modulator, IL10 can both stimulate and suppress the immune response[6]. Numerous studies have shown that IL-10 may be involved in the pathogenesis of cancer, but the results were inconsistent. On the one hand, increased serum IL-10 levels could facilitate development of cancer by suppressing expression of MHC class I and II antigens[7] and preventting tumor antigen presentation to CD8-cytotoxic T lymphocytes. On the other hand, antiangiogenic effects of IL-10 are supposed to play a protective and preventive role against tumor.

The gene encoding IL-10 is located on human chromosome 1q31-1q32[8,9], and is composed of five exons and four introns. It has been reported that several important polymorphic sites in the IL-10 gene, including three in the promoter region $(-1082(\mathrm{~A} / \mathrm{G},-819 \mathrm{~T} / \mathrm{C},-592 \mathrm{~A} / \mathrm{C})$ may influence the transcription of IL-10 messenger RNA and the expression of IL-10 in vitro [10-12]. Although 
Table 1: Primer sequences and reaction conditions for genotyping IL-10 polymorphisms

\begin{tabular}{lllll}
\hline Polymorphism & db SNP ID & PCR Primer sequence & RE & Product size(bp) \\
\hline-1082 A/G & Rs1800870 & F: 5'-CTCGCTGCAACCCAACTGGC-3' & Mnll & G: $106+33$ \\
& & R: 5'-TCTACCTATCCCTACTCC-3' & & A: 139 \\
-819 T/C & Rs1800871 & F: 5-TCATTCTATGTGCTGGAGATGG-3' & Maell & C: $125+84$ \\
& & R: 5'-TGGGGGAAGTGGGTAAGAGT-3' & & A:209 $236+176$ \\
-592 A/C & Rs1800872 & F: 5-GGTGAGCACTACCTGACTAGC-3' & Rsal & C: 412 \\
& & R: 5'-CCTAGGTCACAGTGACGTGG-3' & & \\
\hline
\end{tabular}

Abbreviations: dbSNP ID, database identifier; SNP, single-nucleotide polymorphism; $\mathrm{PCR}$, polymerase chain reaction; RE, restriction endonuclease.

several studies have shown the possible involvement of IL-10 in the pathogenesis of breast cancer, as well as its association with prognosis in different ethnic populations, the results were not all consistent[13]. Furthermore, little is known about the effect of these polymorphisms on the risk of beast cancer in the Han Chinese population. The goal of this study was to evaluate whether IL-10 gene promoter $-1082 \mathrm{~A} / \mathrm{G},-819 \mathrm{~T} / \mathrm{C}$ and $-592 \mathrm{~A} / \mathrm{C}$ polymorphisms and haplotypes were associated with breast cancer in a Han Chinese population.

\section{Materials and methods Subjects}

Blood samples were taken from 315 breast cancer cases and 322 non-cancer controls. The case group was recruited between October 2008 and October 2009 from the Shan Dong Cancer Hospital and the PLA 456 Hospital. The patients' pathological and clinical information were obtained from their medical files. All cases were newly diagnosed and previously untreated. The control group consisted of 322 healthy age-matched women who visited the general health check-up division at the two hospitals in the period between October 2008 and October 2009. Selection criteria for controls were no evidence of any personal or family history of cancer or other serious illness. At recruitment, each participant was personally interviewed to obtain detailed information on demographic characteristics and lifetime history of tobacco and alcohol use. All subjects were unrelated ethnic Han Chinese and residents of northern China. The study has been approved by the Institutional Review Boards of Shan Dong Cancer Hospital and the PLA 456 Hospital. Written informed consent was obtained from all participating subjects.

\section{Polymorphism analysis}

Genomic DNA was isolated from peripheral blood leukocytes of control subjects and breast cancer patients by the salting-out method as described previously [14]. Geno- types were assayed with polymerase chain reactionerestriction fragment length polymorphism(RFLP) methods. The PCR primers were designed based on described previously[15]. The PCR was performed with a $25-\mu \mathrm{L}$ reaction mixture containing $100 \mathrm{ng}$ of genomic DNA, 0.5 $\mu \mathrm{mol} / \mathrm{L}$ of each primer, $200 \mu \mathrm{mol} / \mathrm{L}$ of each dNTP, $2.5 \mathrm{U}$ of Taq DNA polymerase (Omega, Doraville, GA), 10× PCR buffer supplied by Invitrogen Corp $(10 \mathrm{mmol} / \mathrm{l}$ Tris- $\mathrm{HCl}$, $\mathrm{pH} 8.8,50 \mathrm{mmol} / \mathrm{l} \mathrm{KCl}$ ), and $2.0 \mathrm{mmol} / \mathrm{L} \mathrm{MgCl}_{2}$. The PCR profile consisted of an initial melting step of 5 minutes at $94^{\circ} \mathrm{C}$, followed by 35 cycles of 30 seconds at $94^{\circ} \mathrm{C}, 45 \mathrm{sec}-$ onds at $58^{\circ} \mathrm{C}$ for $-1082 \mathrm{~A} / \mathrm{G}, 59^{\circ} \mathrm{C}$ for $-819 \mathrm{~T} / \mathrm{C}$ and $62^{\circ} \mathrm{C}$ for $-592 \mathrm{~A} / \mathrm{C} ; 55 \mathrm{~s}$ at $72^{\circ} \mathrm{C}$; and a final elongation at $72^{\circ} \mathrm{C}$ for $8 \mathrm{~min}$. The restriction endonucleases MnlI, MaeIII, and RsaI (New England Biolabs, Beverly, MA) were used to distinguish the IL-10 gene -1082A/G, -819T/C, -592A/ $\mathrm{C}$ polymorphisms, respectively (Table1). To confirm the genotyping results, PCR-amplified DNA samples were examined by DNA sequencing, and the results were 100\% concordant (data not shown).

\section{Statistical analysis}

Genotype and allele frequencies of IL-10 were compared between breast cancer cases and controls by the chisquared test or Fisher's exact test when necessary. The odds rations (OR) and $95 \%$ confidence interval (CI) were calculated to estimate the relative risk conferred by a particular allele and genotype. Demographic and clinical data between groups were compared by chi-squared test and by Student's t-test. Statistical significance was assumed at the $p<0.05$ level. The SPSS for Windows (version 13.0; SPSS, Inc) was used for all of the statistical analysis.

\section{Results}

\section{Subject characteristics}

The demographics of the cases and controls enrolled in this study are summarized in Table2. There were no statistically significant differences between the cases and 
Table 2: Characteristics of patients with breast cancer and healthy controls

\begin{tabular}{|c|c|c|c|}
\hline \multirow[t]{2}{*}{ Variable } & Patients, no. (\%) & Controls, no. (\%) & \multirow[t]{2}{*}{$P$-value } \\
\hline & $n=315$ & $n=322$ & \\
\hline Age(year) & & & 0.979 \\
\hline$<48$ & $165(52.4)$ & $169(52.5)$ & \\
\hline$\geq 48$ & $150(47.6)$ & $153(47.5)$ & \\
\hline Menopausal status & & & 0.593 \\
\hline Premenopausal & $144(45.7)$ & $154(47.8)$ & \\
\hline Postmenopausal & $171(54.3)$ & $168(52.2)$ & \\
\hline \multicolumn{4}{|l|}{ Tumor size (cm) } \\
\hline$<2$ & $104(33.0)$ & & \\
\hline $2 \sim 5$ & $167(53.0)$ & & \\
\hline$\geq 5$ & $44(14.0)$ & & \\
\hline \multicolumn{4}{|l|}{ LN involvement } \\
\hline Positive & $117(37.1)$ & & \\
\hline Negative & $198(62.9)$ & & \\
\hline \multicolumn{4}{|l|}{ ER expression } \\
\hline Positive & $169(53.7)$ & & \\
\hline Negative & $146(46.3)$ & & \\
\hline \multicolumn{4}{|l|}{ PR expression } \\
\hline Positive & $166(52.7)$ & & \\
\hline Negative & $149(47.3)$ & & \\
\hline
\end{tabular}

Table 3: Genotype and allele frequencies of IL-10 promoter polymorphisms in breast cancer patients and healthy controls

\begin{tabular}{|c|c|c|c|c|c|c|c|}
\hline \multirow[b]{2}{*}{ Genetype } & \multicolumn{2}{|c|}{ Frequency, no.(\%) } & \multirow[b]{2}{*}{$P$-value } & \multirow[b]{2}{*}{ Alleles } & \multicolumn{2}{|c|}{ Frequency, no.(\%) } & \multirow[b]{2}{*}{$P$-value } \\
\hline & $\begin{array}{l}\text { Patients } \\
\mathbf{n}=\mathbf{3 1 5}\end{array}$ & $\begin{array}{l}\text { Controls } \\
n=322\end{array}$ & & & $\begin{array}{l}\text { Patients } \\
2 n=630\end{array}$ & $\begin{array}{l}\text { Controls } \\
2 n=644\end{array}$ & \\
\hline$-1082 \mathrm{~A} / \mathrm{G}$ & & & 0.664 & $-1082 \mathrm{~A} / \mathrm{G}$ & & & 0.374 \\
\hline$A A$ & $285(90.5)$ & $285(88.5)$ & & $A$ & $599(95.1)$ & $605(93.9)$ & \\
\hline$A G$ & $29(9.2)$ & 35 (10.9) & & G & $31(4.9)$ & $39(6.1)$ & \\
\hline GG & $1(0.3)$ & $2(0.6)$ & & & & & \\
\hline$-819 \mathrm{~T} / \mathrm{C}$ & & & 0.604 & $-819 \mathrm{~T} / \mathrm{C}$ & & & 0.315 \\
\hline$\pi$ & $119(37.8)$ & 134 (41.6) & & $\mathrm{T}$ & $373(59.2)$ & $399(62.0)$ & \\
\hline TC & $135(42.9)$ & $131(40.7)$ & & $\mathrm{C}$ & $257(40.8)$ & $245(38.0)$ & \\
\hline CC & $61(19.3)$ & $57(17.7)$ & & & & & \\
\hline$-592 \mathrm{~A} / \mathrm{C}$ & & & 0.604 & $-592 \mathrm{~A} / \mathrm{C}$ & & & 0.315 \\
\hline$A A$ & $119(37.8)$ & $134(41.6)$ & & A & $373(59.2)$ & $399(62.0)$ & \\
\hline$A C$ & $135(42.9)$ & $131(40.7)$ & & C & $257(40.8)$ & $245(38.0)$ & \\
\hline CC & $61(19.3)$ & $57(17.7)$ & & & & & \\
\hline
\end{tabular}


Table 4: Genotype frequencies of IL-10 and clinicopathologic features of breast cancer patients

\begin{tabular}{|c|c|c|c|c|c|}
\hline \multirow{2}{*}{$\begin{array}{c}\text { Clinicopathologic } \\
\text { features }\end{array}$} & \multirow[t]{2}{*}{$n$} & \multicolumn{2}{|c|}{ Genetype (\%) } & \multirow[t]{2}{*}{$x^{2}$} & \multirow[t]{2}{*}{$p$} \\
\hline & & AA & AG+GG & & \\
\hline ER expression & & & & 0.001 & 0.971 \\
\hline Positive & 169 & $153(90.5)$ & $16(9.5)$ & & \\
\hline Negative & 146 & $132(90.4)$ & $14(9.6)$ & & \\
\hline PR expression & & & & 0.209 & 0.647 \\
\hline Positive & 166 & $149(89.8)$ & $17(10.2)$ & & \\
\hline Negative & 149 & $136(91.3)$ & $13(8.7)$ & & \\
\hline Tumor size $(\mathrm{cm})$ & & & & 6.471 & 0.039 \\
\hline$<2$ & 104 & $88(84.6)$ & $16(15.4)$ & & \\
\hline $2 \sim 5$ & 167 & $155(92.8)$ & $12(7.2)$ & & \\
\hline$\geq 5$ & 44 & $42(95.5)$ & $2(4.5)$ & & \\
\hline LN involvement & & & & 4.174 & 0.041 \\
\hline Negative & 198 & $174(87.9)$ & $24(12.1)$ & & \\
\hline Positive & 117 & 111 (94.9) & $6(5.1)$ & & \\
\hline
\end{tabular}

controls for the age, menopausal status $(P=0.979$ and $P=$ 0.593 , respectively), and this suggested that the matching based on these two variables was adequate.

\section{Genotype and allele frequencies}

The genotype and allele frequencies of the IL-10 gene polymorphisms in breast cancer patients and healthy controls are show in Table3. The genotypes were found to be in Hardy-Weinberg equilibrium in both case and control groups. Statistical analysis, however, revealed no significant differences in the genotype and allele frequencies at all three SNP sites between patients and healthy controls. In addition to overall comparisons, the genotype frequencies were compared in subgroups classified according to menopausal status and no association was found between genotypes and risk of breast cancer.

Analysis of association between genotypes and clinicopathologic features of breast cancer revealed no associa- tion between genotypes at these positions and ER expression and PR expression. Tumor size was significantly different between carriers of the AA genotype at position $-1082 \mathrm{~A} / \mathrm{G}$ in comparison to other genotypes ( $P$ $=0.039)$. In addition, LN involvement was significantly lower in patients harboring at least one $G$ allele at position -1082 A/G (AG and GG genotypes) in comparison to patients with the AA genotype $(P=0.041)$. (Table4)

\section{Haplotypes analysis}

The estimated haplotype frequencies of IL-10 polymorphisms in breaste cancer patients and controls are shown in Table5. Complete linkage disequilibrium was observed between locus $-819 \mathrm{~T} / \mathrm{C}$ and locus $-592 \mathrm{~A} / \mathrm{C}$. Four possible haplotypes were demonstrated in our population. The most frequent haplotype in both patients and controls was ATA haplotype(harboring wild type alleles of all three positions and with $56.5 \%$ frequency in patients vs.

Table 5: Frequencies of IL-10 Haplotypes $(-1082,-810,-592)$ in breast cancer patients and healthy controls

\begin{tabular}{|c|c|c|c|c|}
\hline & Patients, no. (\%) & Controls, no. (\%) & & \\
\hline Possible haplotype & $2 n=630$ & $2 n=644$ & $x^{2}$ & $P$-value \\
\hline ATA & $356(56.5)$ & $377(58.5)$ & 1.857 & 0.603 \\
\hline $\mathrm{ACC}$ & $243(38.6)$ & $228(35.4)$ & & \\
\hline GTA & $17(2.7)$ & $22(3.4)$ & & \\
\hline GCC & $14(2.2)$ & $17(2.6)$ & & \\
\hline
\end{tabular}


Table 6: Frequencies of IL-10 Haplotypes(-1082, -810, -592) and clinicopathologic features of breast cancer patients

\begin{tabular}{|c|c|c|c|c|c|}
\hline \multirow[b]{2}{*}{$\begin{array}{l}\text { Clinicopathologic } \\
\text { features }\end{array}$} & \multirow[b]{2}{*}{$2 n$} & \multicolumn{2}{|c|}{ haplotype (\%) } & \multirow[b]{2}{*}{$x^{2}$} & \multirow[b]{2}{*}{$p$} \\
\hline & & ATA & non-ATA & & \\
\hline ER expression & & & & 0.026 & 0.872 \\
\hline Positive & 338 & $192(56.8)$ & $146(43.2)$ & & \\
\hline Negative & 292 & $164(56.2)$ & $128(43.8)$ & & \\
\hline PR expression & & & & 0.010 & 0.922 \\
\hline Positive & 332 & $187(56.3)$ & $145(43.7)$ & & \\
\hline Negative & 298 & $169(56.7)$ & $129(43.3)$ & & \\
\hline Tumor size (cm) & & & & 7.180 & 0.028 \\
\hline$<2$ & 208 & $105(50.5)$ & $103(49.5)$ & & \\
\hline $2 \sim 5$ & 334 & $192(57.5)$ & $142(42.5)$ & & \\
\hline$\geq 5$ & 88 & $59(67.0)$ & $29(33.0)$ & & \\
\hline LN involvement & & & & 5.246 & 0.022 \\
\hline Negative & 396 & $210(53.0)$ & $186(47.0)$ & & \\
\hline Positive & 234 & $146(62.4)$ & 88 (37.6) & & \\
\hline
\end{tabular}

$58.5 \%$ in controls). The frequencies of haplotype were investigated and no significant differences were observed between patients and healthy controls.

Analysis of breast cancer prognostic and predictive factors revealed that ATA haplotype was associated with a significantly increased risk of lymph node metastasis at the time of diagnosis as compared with other haplotypes $(P=0.022)$. In addition, we also found strong association between tumor size and the ATA haplotypes $(P=$ 0.028). (Table6)

\section{Discussion}

In this case-control study we evaluated the association between the polymorphisms of the IL-10 promoter and breast cancer in a Han Chinese population. Our data did not show significant differences in allele, genotype and haplotype frequencies between breast cancer patients and healthy controls. In concordance with our study, Howell et al.[16], Smith et al. [17] and Balasubramanian et al.[18] reported that there were no apparent relationship of the IL-10 gene promoter polymorphisms with the risk of breast cancer. However, these results are not consistent with the study conducted in Austrian previously, in which the -592AA genotype was shown to be associated with a reduced breast cancer risk[19]. Moreover, another study from the Italian population showed that the IL-10 -1082AA genotype was correlated with a marked increase in breast cancer risk[20]. Although it is difficult to determine the reasons behind the contradictory results in these studies, the different genetic back- ground of study population may be one of the main factors

In this study, we found that the frequencies of the -1082 $\mathrm{G},-819 \mathrm{C}$ and $-592 \mathrm{C}$ alleles among the healthy controls (0.061, 0.380 and 0.380 , respectively) were similar to those observed in an Asian population[21,22] but significantly lower than those of European Caucasians [23-25]. We also found that there was strong linkage disequilibrium among the $-1082 \mathrm{~A} / \mathrm{G},-819 \mathrm{~T} / \mathrm{C}$ and $-592 \mathrm{~A} / \mathrm{C}$ polymorphisms. Complete linkage disequilibrium was observed between locus $-819 \mathrm{~T} / \mathrm{C}$ and locus $-592 \mathrm{~A} / \mathrm{C}$. Four possible haplotypes were demonstrated in our population. Major haplotype frequency of the ATA among the controls in the present study was 0.585 , which was significantly higher than those of study performed in the European Caucasians $(0.290$ and 0.248 , respectively)[24,26]. These results suggest that the frequencies of IL-10 gene alleles and haplotypes might vary among the different ethnic population.

Although we did not find an association of the IL-10 gene polymorphisms with risk of breast cancer, in present study we reported for the first time that the IL-10 promoter haplotypes and $-1082 \mathrm{~A} / \mathrm{G}$ polymorphism were significantly associated with the prognostic and predictive factors of breast cancer in Chinese han women. Our data showed that the $-1082 \mathrm{AA}$ genotype was associated with a significantly increased risk of lymph node (LN) involvement $(P=0.041)$ and larger tumor size $(P=0.039)$ at the time of diagnosis. Moreover, in the haplotype analysis of IL-10 gene, we also found that patients carrying 
ATA haplotype were in higher LN involvement $(p=$ $0.022)$ and higher tumor stage $(p=0.028)$ of breast cancer at the time of diagnosis compared with others. The findings suggest that the IL-10 ATA haplotype and -1082AA genotype might be adverse prognostic factors in breast cancer in Chinese Han women.

IL-10 is a multifunctional cytokine with both immunosuppressive and antiangiogenic functions, which may play varied roles in the pathogenesis and development of breast cancer. Although the genetic control of IL-10 expression is not clearly understood yet, polymorphisms in promoter have been reported to determine interindividual differences in IL-10 production[4,9]. Previous studies indicated that IL-10 promoter -1082 AA genotype was associated with decreased IL-10 expression[27]. ATA haplotype formed by polymorphisms at positions $-1,082$, -819 and -592 in the promoter of the IL-10 gene has been is generally assumed to be a lower IL-10 responder[1012]. This and the present study indicate that low levels of IL-10 may play a facilitative role in the development of breast cancer. Findings of our study are further supported by a recent study showing that the low-expression allele and haplotype were associated with reduced disease-free survival and the IL-10 gene polymorphisms may be a potential prognosis marker in breast cancer for diseasefree survival[28]. The mechanism for this remains unclear, but may likely include anti-angiogenic functions of IL-10.

In conclusion, in this case-control study, we report for the first time that the IL-10 promoter polymorphisms were significantly associated with the prognostic and predictive factors of breast cancer in a Chinese han population. The main finding of our study suggests that IL-10 promoter polymorphisms participate in the progression of breast cancer rather than in its initial development. Considering limited sample size, nonrandom sampling and pitfalls of unknown confounders, further studies with larger sample size from different ethnic origins are required to confirm and extend our observations. In addition, more studies should be carried out to clarify the exact molecular mechanism of IL-10 polymorphisms effects.

\section{Competing interests}

The authors declare that they have no competing interests.

\section{Authors' contributions}

WL, FK and JL designed the study, collected the materials, performed all experiments, YL drafted the manuscript. BS and HW participated in the study and performed the statistical analysis. All authors read and approved the final version manuscript.

\section{Acknowledgements}

This work was financially supported by a grant from the National Natural Science Foundation of China (No. 30973437)

\section{Author Details}

1 Department of Oncology, State Key Discipline of Cell Biology, Xijing Hospital, Fourth Military Medical University, 710032, Xi'an, PR China, 2Department of Oncology, the 456 Hospital of Chinese PLA, 250031, Jinan, PR China,

3Department of Oncology, Shandong Cancer Hospital \& Institute, 250031 Jinan, PR China, ${ }^{4}$ Department of Oncology, Guang'anmen Hospital, China Academy of Chinese Medical Sciences, 100053, Beijing, PR China and 5Department of Basic Research Center, Shandong Cancer Hospital \& Institute, 250031, Jinan, PR China

Received: 26 April 2010 Accepted: 17 June 2010

Published: 17 June 2010

\section{References}

1. Kamangar F, Dores GM, Anderson WF: Patterns of cancer incidence, mortality, and prevalence across five continents:defining priorities to reduce cancer disparities in different geographic regions of the world. J Clin Oncol 2006, 24(14):2137-2150.

2. Smyth MJ, Cretney E, Kershaw MH, Hayakawa Y: Cytokines in cancer immunity and immunotherapy. Immunol Rev 2004, 202:275-293.

3. Mocellin S, Marincola F, Rossi CR, Nitti D, Lise M: The multifaceted relationship between IL-10 and adaptive immunity:putting together the pieces of a puzzle. Cytokine Growth Factor.Rev 2004, 15:61-76.

4. Turner DM, Williams DM, Sankaran D, Lazzarus M, Sinnott PJ, Hutchinson IV: An investigation of polymorphism in the interleukin-10 gene promoter. Eur JImmunogenet 1997, 24:1-8.

5. Gibson AW, Edberg JC, Wu J, Westendorp RG, Huizinga TW, Kimberly RP: Novel single nucleotide polymorphisms in the distal IL-10 promoter affect IL-10 production and enhance the risk of systemic lupus erythematosus. J Immunol 2001, 166:3915-3922.

6. Mocellin S, Marincola FM, Young HA: Interleukin-10 and the immune response against cancer: a counterpoint. J Leukoc Biol 2005, 78:1043-1051

7. Matsuda M, Salazar F, Petersson M, Masucci G, Hansson J, Pisa P: Interleukin 10 pretreatment protects target cells from tumor- and allospecific cytotoxic T cells and downregulates HLA class I expression. J Exp Med 1994, 180:2371-2376.

8. Kim JM, Brannan Cl, Copeland NG: Structure of the mouse IL-10 gene and chromosomal localization of the mouse and human genes. $J$ Immunol 1992, 148:3618-3623.

9. Eskdale J, Kube D, Tesch H: Mapping of the human IL10 gene and further characterization of the 5 'flanking sequence. Immunogenetics 1997, 46:120-128.

10. Kingo K, Ratsep R, Koks S, Karelson M, Silm H, Vasar E: Influence of genetic polymorphisms on interleukin-10 mRNA expression and psoriasis susceptibility. J Dermatol Sci 2005, 37:111-113.

11. Crawley E, Kay R, Sillibourne J, Patel P, Hutchinson I, Woo P: Polymorphic haplotypes of the interleukin-10 5'flanking region determine variable interleukin-10 transcription and are associated with particular phenotypes of juvenile rheumatoid arthritis. Arthritis Rheum 1999, 42:1101-1108

12. Hoffmann SC, Stanley EM, Darrin E Cox, Craighead N, DiMercurio BS, Koziol DE, Harlan DM, Kirk AD, Blair PJ: Association of cytokine polymorphic inheritance and in vitro cytokine production in anti-CD3/CD28stimulated peripheral blood lymphocytes. Transplantation 2001 72:1444-1450.

13. Howell WM, Rose-Zerilli MJ: Cytokine gene polymorphisms, cancer susceptibility, and prognosis. J Nutr 2007, 137(1 Suppl):194S-199S.

14. John SW, Weitzner G, Rozen R, Scriver CR: A rapid procedure for extracting genomic DNA from leukocytes. Nucleic Acids Res 1991, 19:408.

15. Shih CM, Lee $Y L$, Chiou HL: The involvement of genetic polymorphism of IL-10 promoter in non-small cell lung cancer. Lung Cancer 2005, 50(3):291-297.

16. Howell WM, Rose-Zerilli MJ: Interleukin- 10 polymorphisms, cancer susceptibility and prognosis. Fam Cancer 2006, 5(2):143-149.

17. Smith KC, Bateman AC, Fussell HM, Howell WM: Cytokine gene polymorphisms and breast cancer susceptibility and prognosis. Eur J Immunogenet 2004, 31:167-173. 
18. Balasubramanian SP, Azmy IA, Higham SE: Interleukin gene polymorphisms and breast cancer: a case control study and systematic literature review. BMC Cancer 2006, 6:188.

19. Langsenlehner U, Krippl P, Renner W, Yazdani-Biuki B, Eder T, Koppel H, Wascher TC, Paulweber B, Samonigg H: Interleukin- 10 promoter polymorphism is associated with decreased breast cancer risk. Breast Cancer Res Treat 2005, 90:113-5.

20. Giordani L, Bruzzi P, Lasalandra C, Quaranta M, Schittulli F, Della F Ragione, Iolascon A: Polymorphisms of Interleukin-10 and tumour necrosis factor-a gene promoter and breast cancer risk. Clin Chem 2003, 49:1664-1667.

21. Meenagh A, Willians F, Ross OA: Frequency of cytokinepolymor phisms in populations from western Europe, Africa, Asia, the Middle East and South America. Human Immunol 2002, 63:1055-1061.

22. Chin HJ, Na KY, Kim SJ: Interleukin- 10 promoter polymorphism is associated with the predisposition to the development of $\lg A$ nephropathy and focal segmental glomeruloselerosis in Korea. $J$ Korean Med Sci 2005, 20(6):989-993.

23. Alonso R, Suarez A, Castro P, Lacave AJ, Gutierrez C: Influence of interleukin-10 genetic polymorphism on survival rates in melanoma patients with advanced disease. Melanoma Res 2005, 15:53-60.

24. Scassellati C, Zanardini R, Squitti R: Promoter haplotypes of interleukin10 gene and sporadic Alzheimer's disease. Neurosci Lett 2004, 35:119-122.

25. Poli F, Nocco A, Berra S: Allelle frequencies of polymorphisms of TNFa, IL-6, IL-10 and IFN G in an Italian Caucasian population. Eur J Immunogrnet 2002, 29(3):237-240.

26. Mangia A, Santoro R, Piattelli M: IL- 10 haplotypes as possible predictors of spontaneous clearance of HCV infection. Cytokine 2004, 25:103-109.

27. Eskdale J, Gallagher : A polymorphic dinucleotide repeat in the human IL-10 promoter. Immunogenetics 1995, 42:444-445.

28. Gerger A, Renner W, Langsenlehner T, Hofmann G, Knechtel G, Szkandera J, Samonigg H, Krippl P, Langsenlehner U: Association of interleukin-10 gene variation with breast cancer prognosis. Breast Cancer Res Treat 2010, 119:701-705.

doi: 10.1186/1756-9966-29-72

Cite this article as: Kong et al., Association of interleukin-10 gene polymorphisms with breast cancer in a Chinese population Journal of Experimental \& Clinical Cancer Research 2010, 29:72

\section{Submit your next manuscript to BioMed Central} and take full advantage of:

- Convenient online submission

- Thorough peer review

- No space constraints or color figure charges

- Immediate publication on acceptance

- Inclusion in PubMed, CAS, Scopus and Google Scholar

- Research which is freely available for redistribution

Submit your manuscript at www.biomedcentral.com/submit
C Biomed Central 